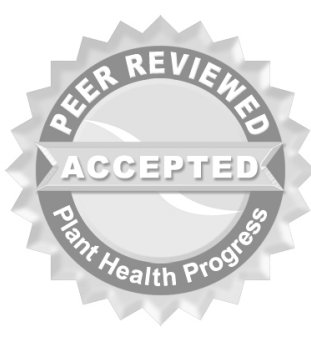

(c) 2010 Plant Management Network.

Accepted for publication 4 J anuary 2010. Published 15 March 2010.

\title{
First Report of Powdery Mildew of Tecoma capensis Caused by Erysiphe peruviana in North America
}

Dean A. Glawe and Tess Barlow, Department of Plant Pathology, Washington State University, and College of Forest Resources, Box 352100, University of Washington, Seattle, WA 98195;

Michael E. Matheron, The University of Arizona, Yuma Agricultural Center, 6425 W. Eighth Street, Yuma, AZ 85364

Corresponding author: Dean A. Glawe. glawe@wsu.edu

Glawe, D. A., Barlow, T., and Matheron, M. E. 2010. First report of powdery mildew of Tecoma capensis caused by Erysiphe peruviana in North America. Online. Plant Health Progress doi: 10.1094/PHP-2010-0315-04-BR.

Tecoma capensis (Thunb.) Lindl. (Bignoniaceae, common name: Cape honeysuckle), native to southern Africa, is grown as an ornamental plant in warm regions of the USA. The powdery mildew reported previously from $\mathrm{T}$. capensis in North America was an undetermined Oidium species in Florida (2). The present report documents the occurrence of the powdery mildew fungus Erysiphe peruviana (Syd.) U. Braun \& S. Takam. on T. capensis in Arizona.

Powdery mildew was observed on a specimen plant growing in a private garden in Yuma, Yuma Co., AZ, in April of 2008 and 2009. The disease was apparent until about mid-May. Disease signs included effuse, whitish colonies on adaxial leaf surfaces (Fig. 1). Infections occurred on foliage receiving little or no direct sunlight, and no significant damage occurred. Infected leaflets and leaves eventually abscised. No new infections were observed after early May. The fungus formed ectophytic hyphae with lobed appressoria (Fig. 2); cylindrical conidiophore foot cells (Fig. 3) measuring (15.5-) 16-19(-20.5) × 5.57.5(-9.5) $\mu \mathrm{m}$; and ovoid to cylindrical conidia (Fig. 4) without fibrosin bodies, measuring (25-)26-37(-40.5) $\times(12-) 13-16.5(-17.5) \mu \mathrm{m}$. The teleomorph was lacking. DNA was extracted and an ITS sequence was obtained as described previously (3). BLAST searches of the NCBI nucleotide database (www.ncbi.nlm.nih.gov) indicated that the sequences with highest similarity were from Erysiphe pisi (97\% identity) and E. diffusa (96\% identity). No sequences from E. peruviana were available for comparison. A voucher specimen was deposited with the Mycological Herbarium at Washington State University. The ITS sequence was deposited with NCBI.

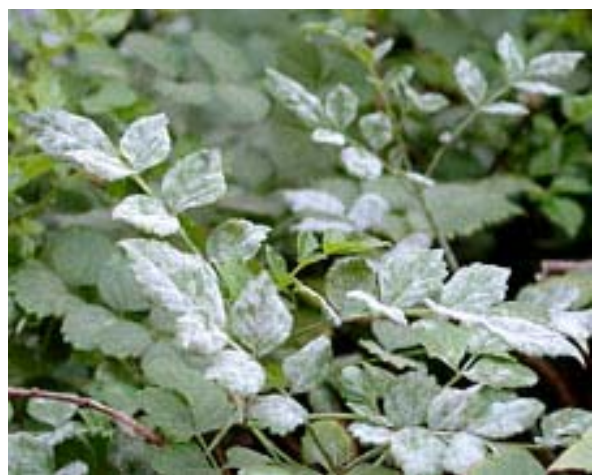

Fig. 1. Signs of powdery mildew of Tecoma capensis.

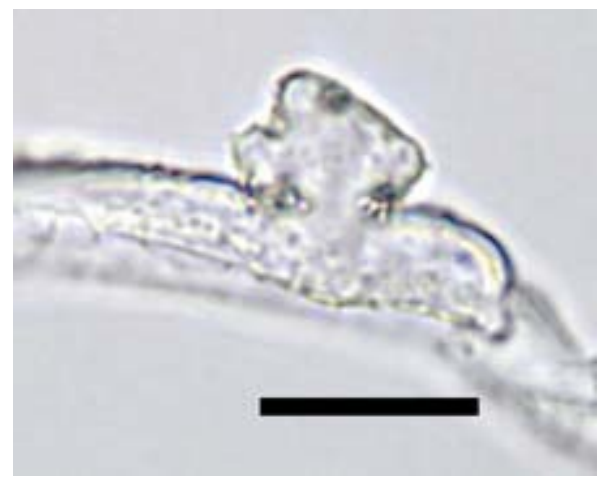

Fig. 2. Appressorium formed by Erysiphe peruviana on Tecoma capensis. Scale bar $=10 \mu \mathrm{m}$ 

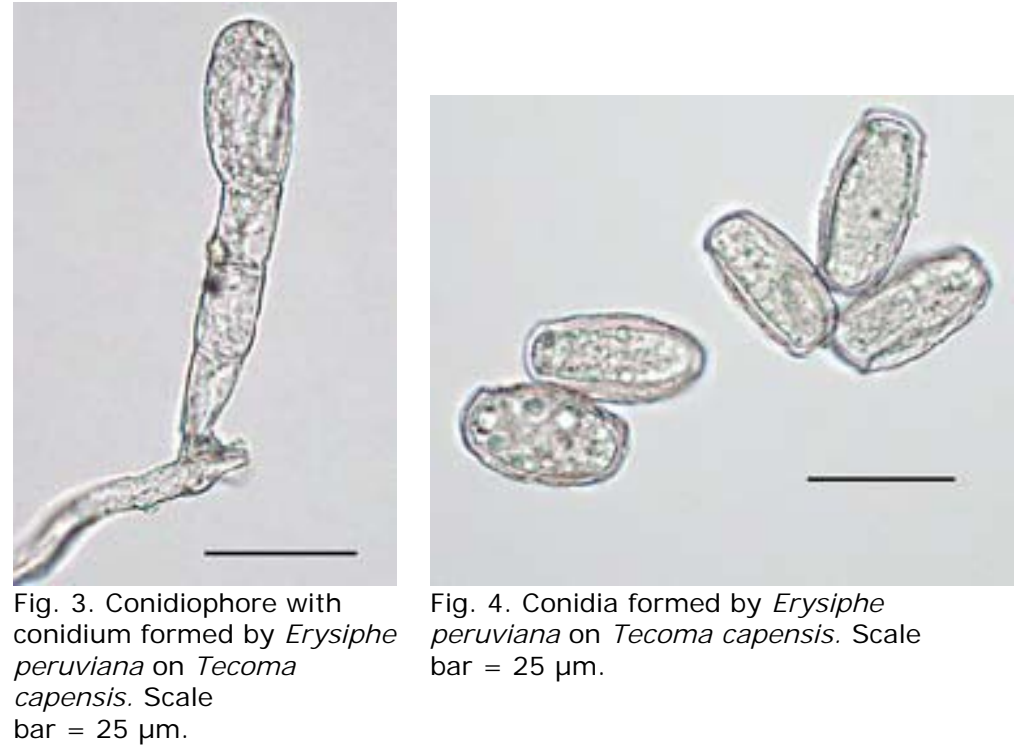

Fig. 4. Conidia formed by Erysiphe peruviana on Tecoma capensis. Scale bar $=25 \mu \mathrm{m}$.

The fungus was determined to be Erysiphe peruviana on the basis of anamorph morphology and host; the sequence of the ITS region provided information that helped exclude this fungus from other named species. Braun (1) reported two powdery mildews from Tecoma species, E. peruviana and Ovulariopsis obclavata Wakef. The present fungus formed ectophytic hyphae, lobed appressoria, and conidiophores with single conidia, all features characteristic of anamorphs of Erysiphe spp. (3) rather than the clavate to angular conidia characteristic of Ovulariopsis (1). Consistent with morphological information was the fact that the ITS sequence was most similar to those of Erysiphe species represented in GenBank rather than sequences from other genera of Erysiphales. Braun (1) included no information on the anamorph of E. peruviana. A later description (4) of the anamorph of E. peruviana was consistent with features we observed.

Braun (1) listed four other Erysiphe species on bignoniaceous hosts, two of which are represented in the NCBI nucleotide database. That from E. catalpae Simonyan exhibited 92\% identity with the sequence we determined, while that from E. elevata (Burrill) U. Braun \& S. Takam. exhibited 95\% identity. In contrast, ITS sequences for E. pisi, E. diffusa, E. betae, and E. cruciferarum exhibited 96 to $97 \%$ identity to it.

Erysiphe peruviana was reported previously from South America $(1,4)$. Further research would be useful to assess whether it could infect species other than T. capensis because species of Bignoniaceae native to North America could be at risk.

\section{Literature Cited}

1. Braun, U. 1987. A monograph of the Erysiphales (powdery mildews). Beih. Nova Hedwigia 89:1-700.

2. Farr, D. F., Rossman, A. Y., Palm, M. E., and McCray, E. B. 2010. Fungal Databases. Online. Systematic Mycology and Microbiology Laboratory, USDA-ARS, Washinton, DC.

3. Glawe, D. A., Dugan, F. M., Liu, Y., and Rogers. J. D. 2005. First record and characterization of a powdery mildew (Erysiphales) on a member of the Juncaginaceae: Leveillula taurica on Triglochin maritima. Mycol. Prog. 4:291298.

4. Inacio, C. A., and Dianese, J. C. 1998. Some foliicolous fungi on Tabebuia species. Mycol. Res. 102:695-708. 